\title{
Soneto para asesinar a un ave sin interrumpir su vuelo
}

\section{Brian Durán-Fuentes}

\section{Soneto para asesinar a un ave sin interrumpir su vuelo}

Si merito sobra por celebrarse,

Aún por el aplauso gris y discreto

De páginas cual aguas al cerrarse,

Aun por el menor de los pensamientos

Y de las más desechables emociones,

Que no se le apremie a la poesía.

$Y$ al poeta que lo quemen en vida,

Que no se conserve de él ni su nombre.

El acero y bronce le pertenecen

No en sus manos, mas sí sobre sus ojos

Cuando cerrados un rumbo le conceden.

Así la poesía se queda sin rostro

Y espera desnuda en el mismo muelle

Que un niño la cante de nuevo, de pronto.

\section{Quecholli}

No olvida el noble ciervo

tras las sendas su pasado, ni se fía del futuro, pero bebe cantos rojos que se desbordan y arden 
en las sienes de los niños.

Por los cielos va Mixcóatl

danzando en espirales.

Mira la lumbre descender.

Hazme preso, amor mío, a besos roba mi carne, de mi piel haz tu rebozo, luego vámonos al lago en donde los dos nacimos

y las espátulas alcanzan los astros.

\section{El viejo sitio}

Viajero, veo tu espalda

Cubierta con alas grises.

Mientras vas por do viniste,

Arriba florece el alba.

A este árbol buscabas

Y aún sobre piedras vive,

Aún beben las raíces

Aguas ocultas en la nada.

Colina abajo la sombra

Joven corre cual alguna

Que tiempo atrás tú viste.

Mas los ojos en las hojas

Que crecen en la penumbra

No son ya los que tuviste. 


\title{
Dos haikús
}

Sábado de sol,

La risa de los perros

Quiebra las piedras.

\begin{abstract}
Afuera llueve,
El sueño moja la sal.

Nadie volverá.
\end{abstract}

